Bangladesh J. Plant Taxon. 27(1): 103-111, 2020 (June)

(C) 2020 Bangladesh Association of Plant Taxonomists

\title{
PRELIMINARY TAXONOMIC SURVEY OF AQUATIC PLANTS OF FENI DISTRICT, BANGLADESH
}

\author{
Mohammad Zashim UdDin*and Joton ChandRa PaL \\ Department of Botany, University of Dhaka, Dhaka-1000, Bangladesh
}

Keywords: Preliminary; Taxonomic survey; Aquatic plants; Feni district.

\begin{abstract}
Preliminary taxonomic survey of aquatic plants of Feni district was conducted between July 2016 and June 2017. Traditional taxonomic techniques and random meander methods were applied to record and collect aquatic plant species. A total of 56 aquatic plant species under 29 families were recorded from Feni district. Ecological habitats of aquatic plant species showed variations. Among them, $30 \%$ species prefer to grow near the edge of water, $20 \%$ as rooted submerged, $18 \%$ as rooted emergent, $16 \%$ as free floating, $12 \%$ as rooted floating and $4 \%$ surface creeper in the aquatic habitat. The uses of aquatic plants were showed that $27 \%$ species were used as fodder, $14 \%$ as medicinal, $11 \%$ as vegetable, $11 \%$ as edible fruits, $5 \%$ as duck weeds, $2 \%$ as artifacts and $30 \%$ as others purposes in the study area. Abundance of aquatic plant species in the habitat was showed variations. Among them 9\% was found very abundant, $30 \%$ found common and $61 \%$ found rare in the study area. Based on the field observations and discussion with local people we were able to identify a good number of threats to aquatic plants and also pointed out some conservation measures for them. It was seemed that the species Achyranthes aquatica (thuash), Oenanthe javanica (painnaadani), and Chumannianthus dichotomus (patipata) were found to be limited in distribution outside Feni. These rare species need to be given priority for in situ and ex situ conservation.
\end{abstract}

\section{Introduction}

Plants living in water play multifarious roles including nutrient rotation, sediment stabilization, and the provision of foods and habitats for a variety of fishes and other animals (Chambers et al., 2008; O'Hare et al., 2017). Aquatics act as engineer species (Bouma et al., 2010; Bolpagni and Piotti, 2015) and their eradication cause drastic effect on trophic and functional status of the habitats with water bodies (Scheffer et al., 2003; Soana and Bartoli, 2014). Bangladesh supports a large number of aquatic plant species due to her geomorphological location and also the presence of good number of water bodies and flood plains. These aquatic plant species have the huge potentialities in the sector of ecology, environment and economics. Unfortunately less attention was paid on the aquatic angiosperms of Bangladesh except Khan and Halim (1987). For the management of aquatic flora data base is essential. Otherwise species will be lost before proper documentation in the scientific world. Plant taxonomic survey with aquatic plants has been started in Bengal regions. The most noteworthy works were done by Khan and Halim (1987), Alam et al. (2006), Seker et al. (2013), Mahmuda et al. (2017), Mukhopadhyay et al.(2017) and Alfasane et al. (2010, 2013, 2019a,b). But no works were found on the aquatic flora of Feni district except an ethnobotanical work (Uddin et al. 2014).Moreover, aquatic plants and their habitats are very fragile because of so many factors including dams and diversion, modern agriculture, irrigation, pollutants and also biological invasion. If research steps are not taken timely, species are going to extinct very rapidly before scientific documentation. That is why in the present study an attempt has been made to achieve the following objectives: to conduct the taxonomic survey of aquatic plants with all relevant data and also to find threats and to suggest some conservation measures for the aquatic plants of Feni district.

*Corresponding author, e-mail: zashim01@ gmail.com 


\section{Materials and Methods}

Feni is a south-eastern district of Bangladesh and lies between $22^{\circ} 44^{\prime}$ and $23^{\circ} 17 \mathrm{~N}$ and between $91^{\circ} 15^{\prime}$ and $91^{\circ} 35^{\prime} \mathrm{E}$. The total area of the district is about $990.36 \mathrm{sq}$. $\mathrm{km}$. The district is bounded on the north by Cumilla district and Tripura (India), on the east by Tripura (India), on the south by Chittagong district and on the west by Noakhali district. The district consists of 6 upazilas including Chhagalnaiya, Daganbhuiyan, Feni Sadar, Parshuram, Phulgazi and Sonagazi. The Feni, Selonia, Kohua and Muhuri are the main rivers of this district. There is huge number of manmade ponds present in the district. Maximum areas of Feni are flooded by four main rivers during monsoon. Sea water cannot reach to the cultivated land because of Muhuri dam. The area enjoys tropical climate with high rainfall and flush flood during monsoon period. The dry period the area has gone under boro cultivation using water from Muhuri project, a dam made in the estuary of Feni and Muhuri rivers. The vegetation type is similar to the vegetation of the lower Gangetic plain and other districts in the southern region of the country (Ishaq, 1977).

A number of field works for aquatic plants survey (Hyland, 1972; Alexiades, 1996) were conducted in different seasons of the year between 2016 and 2017. The survey areas were included seasonal and permanent water bodies, flood plains, rivers, ponds, and streams. Special efforts were given to find the species of conservation concern including threatened, endemic and rare. Maximum identifications were done at the field site and in case of confusion in identity, fertile plant specimens were collected and processed using standard herbarium techniques (Hyland, 1972). The Identification and updated nomenclature of the species were confirmed with standard literature (Uddin and Hassan, 2004; Siddiqui et al., 2007; Ahmed et al., 2008a,b; 2009a,b,c,d).Threatened categories of plants were recognized following Khan et al. (2001). Some noxious exotic plant species were also determined comparing with the reports of Hossain and Pasha (2004). Families were determined according to Cronquist (1981). Voucher specimens were deposited at Dhaka University Salar Khan Herbarium (DUSH).

\section{Results and Discussion}

A total of 56 aquatic plant species under 29 families were recorded from Feni district. Among the six aquatic plant families, Poaceae is the most common followed by Cyperaceae, Nymphaeaceae, Pontederiaceae, Hydrocharitaceae, and Najadaceae (Fig. 1). For each species, scientific name, bangle name, family, habitat, status, and uses wherever available are provided (Table 1). Habitats of aquatic plant species were showed variations. Among them, 30\% species prefer to grow near the edge of water, $20 \%$ as rooted submerged, $18 \%$ as rooted emergent, $16 \%$ as free floating, $12 \%$ as rooted floating and $4 \%$ surface creeper in the aquatic habitats (Fig. 2).

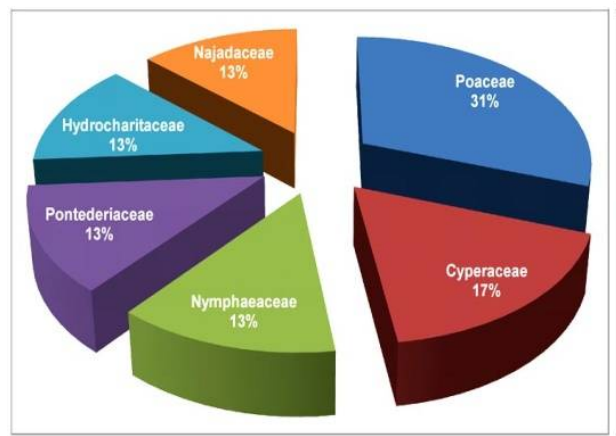

Fig. 1. Six common families of aquatic plants.

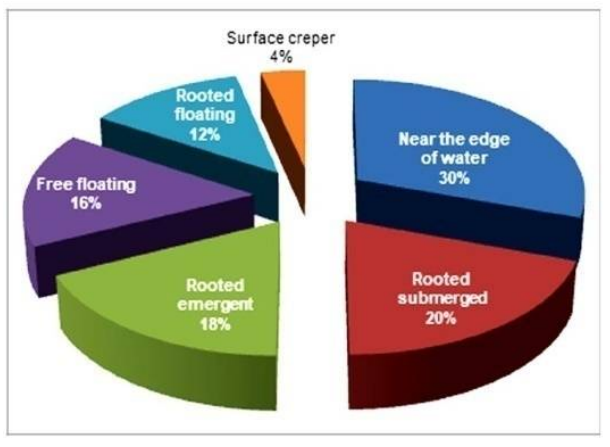

Fig. 2. Habitat diversity of aquatic plants. 
Table 1. Recorded list of aquatic plant species in Feni district.

\begin{tabular}{|c|c|c|c|c|c|}
\hline Scientific name & Local name & Family & Habitat & Uses & Abundance \\
\hline Achyranthes aquatica (R.Br.) Moq. & Thuash & Amaranthaceae & Free floating & Medicinal & + \\
\hline $\begin{array}{l}\text { Actinoscirpus grossus (L.f.) Goetgh. \& } \\
\text { D.A. Simpson }\end{array}$ & Motmotigash & Cyperaceae & Near edge of water & Fodder & ++ \\
\hline Alpinia conchigera Griff. & Taragota & Zingiberaceae & Near edge of water & Medicinal & + \\
\hline $\begin{array}{l}\text { Alternanthera philoxeroides (Mart.) } \\
\text { Griseb. }\end{array}$ & Helencha & Asteraceae & Near edge of water & Vegetable & ++ \\
\hline $\begin{array}{l}\text { Alternanthera sessilis (L.) R. Br. ex } \\
\text { Roem. \& Schult }\end{array}$ & Haincha & Amaranthaceae & Near edge of water & Medicinal & ++ \\
\hline Ammania gracilis Guill and Perr. & - & Lythraceae & Rooted submerged & - & + \\
\hline $\begin{array}{l}\text { Ammania pedicellata (Hiern) } \\
\text { S.A.Graham\& Gandhi }\end{array}$ & - & Lythraceae & Rooted submerged & - & + \\
\hline Apanogeton natans (L.) Engl. \& Krause & Gechu & Aponogatonaceae & Rooted submerged & - & + \\
\hline Aeschynomene indica $\mathrm{L}$. & Shola & Fabaceae & Rooted emergent & Fodder & + \\
\hline Azolla pinnata $\mathrm{R} . \mathrm{Br}$. & Kutipana & Azollaceae & Free floating & $\begin{array}{l}\text { Duck } \\
\text { weed }\end{array}$ & +++ \\
\hline Ceratophyllum submersum L. & Katajhanji & Ceratophyllaceae & Rooted submerged & Fodder & + \\
\hline $\begin{array}{l}\text { Chumannianthus dichotomus (Roxb.) } \\
\text { Gagnep. }\end{array}$ & Patipata & Marantaceae & Near edge of water & Artifact & ++ \\
\hline Colocasia esculenta (L.) Schott & Panikachu & Araceae & Near edge of water & Vegetable & ++ \\
\hline Cyperus articulates $\mathrm{L}$. & - & Cyperaceae & Near edge of water & Fodder & ++ \\
\hline Echinochloa colonum (L.) Link. & Shamagash & Poaceae & Near edge of water & Fodder & + \\
\hline Echinochloa crusgali (L.) P. Beauv. & Hamagash & Poaceae & Near edge of water & Fodder & ++ \\
\hline Eichhornia crassipes (Mart.) Solms. & Kuchripana & Pontederiaceae & Free floating & Fodder & +++ \\
\hline Eleocharis acutangula (Roxb.) Schult. & Chesra & Cyperaceae & Rooted emergent & - & + \\
\hline Enhydra fluctuens Lour. & Tititdata & Asteraceae & Near edge of water & Medicinal & + \\
\hline Hemarthia portensa Steud. & Chaillagash & Poaceae & Near edge of water & Fodder & ++ \\
\hline Hydrilla verticillata (L.f.) Royle & Janji & Hydrocharitaceae & Rooted submerged & - & + \\
\hline Hydrolea zeylanica (L.) Vahl & - & Hydrophyllaceae & Near edge of water & - & ++ \\
\hline Hygrophila phlomoides Nees & - & Acanthaceae & Near edge of water & Medicinal & + \\
\hline Hygrorrhiza aristata (Retz.) Nees & Dolgash & Poaceae & Free floating & Fodder & + \\
\hline Ipomoea aquatica Forssk & Kolmi & Convolvulaceae & $\begin{array}{l}\text { Emergent surface } \\
\text { creeper }\end{array}$ & Vegetable & ++ \\
\hline Ipomoea fistulosa Mart. ex Choisy & Dolkolmi & Convolvulaceae & Near edge of water & Medicinal & ++ \\
\hline Ludwigia adscendens (L.) H. Hara & Molsi & Onagraceae & $\begin{array}{l}\text { Emergent surface } \\
\text { creeper }\end{array}$ & Medicinal & ++ \\
\hline Leersira hexandra Sw. & Araligash & Poaceae & Rooted emergent & Fodder & ++ \\
\hline Lemna minor $\mathrm{L}$. & Khudipana & Lemnaceae & Free floating & $\begin{array}{l}\text { Duck } \\
\text { weed }\end{array}$ & +++ \\
\hline $\begin{array}{l}\text { Limnocharis flava (L.) Buchen. In } \\
\text { Bremen }\end{array}$ & - & Alismataceae & Free floating & - & + \\
\hline Limnophila heterophila (Roxb.) Bentyh. & - & Scrophulariaceae & Rooted submerged & - & + \\
\hline Monochoria hastata (L.) Solms & Boronukha & Pontederiaceae & Rooted emergent & Vegetable & ++ \\
\hline Monochoria vaginalis (Brum. F.) Presl & Nukha & Pontederiaceae & Rooted emergent & Vegetable & ++ \\
\hline Najas gracillima A. Br. ex Mangus & - & Najadaceae & Rooted emergent & - & + \\
\hline Najas graminea Del. & - & Najadaceae & Rooted submerged & - & + \\
\hline Najas marina L. & - & Najadaceae & Rooted emergent & - & + \\
\hline Nechamandra alternifloia (Roxb.) Thw. & - & Hydrocharitaceae & Rooted submerged & - & + \\
\hline Nymphaea nouchali Brum. f. & Neel shapla & Nymphaeaceae & Rooted floating & Edible & + \\
\hline Nymphaea pubescens Willd. & Sadashapla & Nymphaeaceae & Rooted floating & Edible & + \\
\hline
\end{tabular}




\begin{tabular}{|c|c|c|c|c|c|}
\hline Nymphaea rubra Roxb. ex Andr. & Lalshapla & Nymphaeaceae & Rooted floating & Edible & + \\
\hline Nelumbo nucifera Gaertn. & Padma & Nelumbonaceae & Rooted floating & Edible & + \\
\hline $\begin{array}{l}\text { Nymphoides hydrophylla (Lour.) O. } \\
\text { Kunte }\end{array}$ & Toktoi & Menyanthaceae & Rooted floating & Fodder & + \\
\hline Nymphoides indica (L.) O. Kuntze & Chadmala & Menyanthaceae & Rooted floating & Fodder & + \\
\hline Oenanthe javanica (Blume) DC. & Painnaadani & Apiaceae & Near edge of water & Vegetable & + \\
\hline Ottelia alsimoides (L.) Pers. & Panikola & Hydrocharitaceae & Rooted submerged & Edible & ++ \\
\hline Paspalum schorbiculatum $\mathrm{L}$. & - & Poaceae & Near edge of water & Fodder & ++ \\
\hline Persicaria hydropiper (L.) Spach & Bishkatali & Polygonaceae & Near edge of water & Medicinal & + \\
\hline Phragmites karka Trin. & Nolkhagra & Poaceae & Rooted emergent & Fodder & + \\
\hline Pistia stratiotes L. & Molapana & Araceae & Free floating & - & +++ \\
\hline Potamogeton pectinatus $\mathrm{L}$. & Gechu & Potamogetonaceae & Rooted submerged & - & + \\
\hline Sagittaria guayanensis Kunth. & - & Alismataceae & Rooted floating & - & + \\
\hline Schenoplectus articulatus (L.) Palla & Chesra & Cyperaceae & Rooted emergent & - & + \\
\hline Sesbania sesban (L.) Merr. & Fuligash & Fabaceae & Emergent & Fodder & + \\
\hline Trapa bispinosa Roxb. & Shingra & Trapaceae & Free floating & Edible & + \\
\hline Utricularia exoleata $\mathrm{R}$. Br. & Zaji & Lentibulariaceae & Rooted submerged & - & + \\
\hline Wolffia arrhiza (L.) Horkel ex Wimmer & Khudipana & Lemnaceae & Free floating & $\begin{array}{l}\text { Duck } \\
\text { weed }\end{array}$ & +++ \\
\hline
\end{tabular}

Note: + means rare, ++ means common, +++ means abundant.

The study was also recorded the uses of aquatic plant species for different purpose of daily life. Among them, $27 \%$ species were used by local people as fodder, $14 \%$ as medicinal, $11 \%$ as vegetable, $11 \%$ as edible fruits, $5 \%$ as duck weeds, $2 \%$ as artifacts and $30 \%$ as others purposes in the study area (Fig. 3). The abundance of different aquatic species in the habitats was not uniform. Our overall observations showed that $61 \%$ aquatic plant species in the study area were found to be rare, $30 \%$ species were common and $9 \%$ species were abundant (Fig. 4).The results of abundance status of aquatic plant species represented here were based on basically filed observations and discussion with local people in the study area.

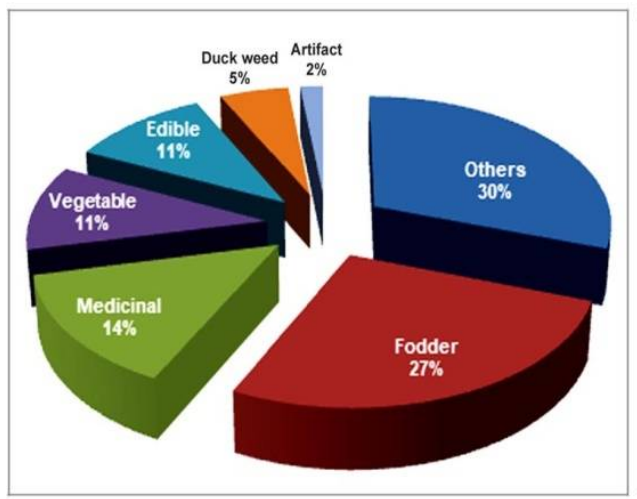

Fig. 3. Different use categories of aquatic plants.



Fig. 4. Abundance of aquatic plant species.

\section{Aquatic plants used as medicines, vegetables and fruits}

In the present preliminary study, some very interesting local uses and distribution of aquatic plant species have been recorded. Achyranthes aquatica locally known as thuash, a free floating aquatic plant is growing on the surface of the ponds and stagnant water bodies. The distribution of this species is very restricted and found only in greater Noakhali district and some parts of 
Chittagong, particularly in Mirsharai. Exploration is needed to find the species in other districts of Bangladesh. Stems are sold in the local market as vegetable. Local people used it to increase appetizer. It has some medicinal properties to cure cough, flue and stomach disorder (Uddin et al., 2014). In case of constipation, the stem paste is very effective. We also assumed that the stem of such plant may reduce blood sugar of human body. Phytochemical and pharmacognosy research are essential to prove the medicinal properties of this plant species. We saw this plant during childhood in west Modhugram of Chhagalnaiya upazila. But it is very difficult to find it now in this area. The species can be propagated through stem cutting. As the species has commercial and medicinal values, conservation effort should be given to protect it from extinction.

Oenanthe javanica, locally called as painnaadani, is an aquatic herb growing near the edge of water. The shoot of this plant is sold in the local market as vegetable. Leaves juice is used to cure jaundice (Uddin et al., 2014). The status of the species is very rare in the study area. We found it in one location in nature and also saw in the market.

Enhydra fluctuans, locally called as Tititdata, is growing near the edge of water bodies. The species is also sold in the local market as vegetable. It has some medicinal properties. Local people used it to cure diabetes and as brain tonic (Uddin et al., 2014). Status of the species in nature is very rare. We found it in one location during our survey.

Ludwigia adscendens locally known as Molsishak, is an aquatic species growing in the surface of water as creeper. The plant shows some visible adaptive feature (white spongy roots) during creeping on the water surface. People used it to cure dysentery and also used as vegetable.

Lasia spinosa locally called it katbash/katakachu, is growing in the wet area of fallow lands. Population status of this species is very rare in the study area. Rhizome of the plant was used by the local people as to cure stomach pain (Uddin et al., 2014) and flowers are used as vegetable.

Alternanthera sessilis locally called it Haincha, is growing near the edge of water bodies. Local people used as vegetable and also used to cure gastric pain. Recent study proved that this species has comparatively better anti-oxygen properties than other less valued wild leafy vegetables (Shethi and Uddin, 2018).

Alternanthera philoxeroides locally called as Helencha, is growing in the edge of water bodies. The species sold in the local market as vegetable. To cure constipation and stomach pain the plant is also used by the local people.

Glynus oppositifolius locally called as Gimashak, a herbaceous plant growing in the wetlands when water was receded out during dry season. Whole plant is sold in the local market as vegetable. It has some medicinal properties. During chest pain cooked plant is used (Uddin et al., 2014).

Nymphaea rubra also called as Lalshapla, an aquatic rooted floating herb is growing in water bodies. It has long petiole with large single flower showing above the water. This petiole is edible and sold in the market. Local people used it to remove constipation and also to reduce blood sugar. Fruits are also edible. In our survey in Feni Lalshapla was found in only one location that means the species is very rare in the natural habitat.

Nymphaea pubescens, called Sadashapla (designated as national flower), is an aquatic rooted free floating herb is growing in the deep water bodies of wetlands. In the local market the petiole is sold as vegetable. Fruits are also edible. People believed that the plant is useful for constipation and diabetes. The population status of this plant species is also rare. During our survey we recorded this species in only one location.

Nelumbo nucifera also called Padma, is an aquatic rooted floating herb growing in water bodies. The flower of the species is very large and showy. The seeds of this species are very favorite to diabetic patients. We spotted this species in one location of Feni district. In the last visit 
we saw the habitat of this species totally altered to urban land for erecting tower building. We assumed that this species is not present other areas of Feni district. Distribution record of this species should be checked before confirming the status in Feni district.

Trapa bispinosa (Singra) is one of the rare aquatic plant species was recorded in the study area. The species was located in only two locations. The population number of this species is very low. Over-exploitation of fruits was one of the major causes to make it rare. Fruits are edible and sell it in the local market.

Ottelia alsimoides locally called it panikola is one of the known edible fruits in aquatic ecosystem. This is very rare in the study area.

\section{Commercially potential plants}

Some ponds and beels of the study area supported profuse growth of duck weeds, particularly Lemna minor, Wolffia arrhiza and Azolla pinnata. Local people harvested these plants and sell them in the market for poultry and fish feeds. Talking to local people we have learned that these plant species have huge market values. If these duck weeds can be cultivated in a planned way then there is a chance to get a lot of financial benefits from them. No investment required to cultivate these species. More over these species can be grown in the stagnant water bodies naturally.

Another interesting species is Chumannianthus dichotomus locally known it as patipata, an aquatic emergent herb is growing in the edge of ponds and water bodies. The plant has high commercial values. Bangladesh forest department introduced it in the commercial plot of wet area of forest lands. Fine mat is making from the peel of the stem of this plant. Mats are used as bed cover, wall mat and handicraft materials. The plant is growing without care. Once planted, the plant can be sprouted from the base of the stem near the root system like bamboos population and continued to grow after generation to generation. Leaves juice are used by the local people to cure ear pain. As you all know that Sheetolpati is very famous in greater Sylhet region. The distribution of this plant is very restricted particularly in few districts.

One rare species growing near the water not listed as aquatic Calamus guruva (Jalibet) is very interesting. This species has been used in different purpose of daily life including binding material. Population of this species was very rare in the study area and listed as threatened species of Bangladesh (Khan et al., 2001). The species was recorded in few locations only.

In our survey number species were also observed those can withstand with waterlogged condition. Barringtonia acutangula (Hizol), Crataeva nurvala (Barun), Pongamia pinnata (Karoj), Trewia nudiflora (Pidali), Syzygium fruticossum (Bhutijam) and Calamus guruva (Jalibet) are the best example of such species. These species are doing well near the water and even inside the water bodies. These species were not listed as aquatics.

\section{Exotics in aquatic ecosystem}

Exotic and invasive species in aquatic ecosystem are great problem to native flora. They have some aggressive features. Using such features they always dominated on the native flora for their survival. Water hyacinth is the best example of invasive species in aquatic bodies of Feni district. This is fast growing aquatic plant quickly covered the surface area of the water bodies and inhibits the growth of light demanding submerged and free floating aquatic plant species. According to local people opinion and our observations revealed that the presence of water hyacinth may create huge problems for other aquatic species including Nymphaea nouchali, Nymphaea rubra, Nymphaea pubescens, Ottelia alismoides, Hydrila verticillata, Potamogeton pectinatus, Utricularia exoleata, Najas graminea, Nymphoides indicum and Trapa bispinosa. They also mentioned that water hyacinth has some positive uses including as fodder to domestic cows and 
buffalos but negative impacts are enormous. In order to maintain native aquatic plant species diversity, water hyacinth should be controlled. During our filed work a number exotic tree species were also observed near the water bodies. These are Samanea saman (Rain tree), Acacia auriculiformis (Akashmoni) and Eucalyptus camaldulensis (Euacalyptus). Local people informed that among the exotics rain tree creates more hazards to local aquatic flora. This species produces spreading canopy and provided shade on the water bodies. Rotten leaves of this tree in the water may also create problems to aquatic plants as well as fishes.

\section{Threats to aquatic flora}

Aquatic plants of Feni district are in vulnerable to extinction because of so many threats. During our exploration and observations in the study area, consultations were made with local people on this issue of threats. Finally a good number of factors were came out those were responsible to make aquatic plants vulnerable to extinction. Among the factors modern agriculture, irrigation, Muhuri dam, herbicide, pollutants from upstream, exotic plantations, wetland filling, biological invasion and lack of awareness are the noteworthy. Muhuri dam is one of the most important threat to the aquatic habitats and aquatic plant diversity and other aquatic animals in the study area as confirmed by our observations and local people opinion.

\section{Conservation measures}

Conservation is a both the matter of investment and insurance that is sustained in the fields of environment, forestry, agriculture and fisheries. It is multidisciplinary approach involved knowledge of many areas including botany, zoology, social sciences, economics and laws (Hunter, 1995). Here as plant taxonomist we tried to focus species composition of the study area, importance of such species, their present status and factors responsible for extinction. Based on our observations and discussion with local people, a number of suggestions were made for the conservation of aquatic plant species in Feni district. First, species those are very rare in the natural habitats need to be located with GIS techniques and try to determine their population status and identify the threats and to minimize that immediately. If the rare species will not be survived in nature that case ex situ measure should be taken for that species particularly Trapa bispinosa, Achyrantehs aquatica, Nymphaea pubescens, Nymphaea rubra, Nymphaea naouchali, Nelumbo nucifera, Aschynomene indica, Oenanthe javanica and Ottelia alsimoides. Propagation and germination experiments initiative should be undertaken to understand their mode of multiplication in nature. Some small areas with full of aquatic plant species should be declared protected for the sources of mother seeds. In this case compensation is necessary for the local people those who own the lands. Awareness among the local people should be created for the importance of aquatic plants in our daily and social life. Herbicide should be banned in the cultivated land to burn weeds, a new threat added to the aquatic life. We should rethink about the benefits and losses of dams and diversion of water. The dam and diversion of water create huge problems to aquatic life in nature as local people informed us.

\section{Conclusions}

The present study in aquatic habitats of Feni district was first initiation. The record 56 aquatic plant species is the good indication of species richness. Further study in the district may enrich the list of aquatic plants. The finding of some interesting rare aquatic plants with their local uses made the demand for their conservation in the aquatic habitats. It was seemed that the species Achyrantehs aquatica (thuash), Oenanthe javanica (painnaadani), and Chumannianthus dichotomus (patipata) were found to be limited in distribution outside Feni. These rare species need to be given priority for the conservation either in natural habitats or at the ponds otherwise it will be lost from the nature before known to scientific world for the evaluation of their medicinal 
properties. The presence of Muhuri dam (an irrigation project) is one of the strongest divers for the elimination of aquatic plant species from the nature. As the results of the present study are very preliminary, sound conclusion was not possible here. Further long term study is needed.

\section{Acknowledgement}

The Principle investigator of the project is greatly acknowledged the financial contribution of the University Grants Commission and the University of Dhaka. He is also thankful to the research assistants and local people during data collection.

\section{References}

Ahmed, Z.U., Begum, Z.N.T., Hassan, M.A., Khondker, M., Kabir, S.M.H., Ahmad, M., Ahmed, A.T.A., Rahman, A.K.A. and Haque, E.U. (Eds) 2008a. Encyclopedia of Flora and Fauna of Bangladesh, Vol. 6. Angiosperms: Dicotyledons (Acanthaceae - Asteraceae). Asiatic Society of Bangladesh, Dhaka, pp. $1-408$.

Ahmed, Z.U., Hassan, M.A., Begum, Z.N.T., Khondker, M., Kabir, S.M.H., Ahmad, M., Ahmed, A.T.A., Rahman, A.K.A. and Haque, E.U. (Eds) 2008b.Encyclopedia of Flora and Fauna of Bangladesh, Vol. 12. Angiosperms: Monocotyledons (Orchidaceae - Zingiberaceae). Asiatic Society of Bangladesh, Dhaka, pp. 1-552.

Ahmed, Z.U., Hassan, M.A., Begum, Z.N.T., Khondker, M., Kabir, S.M.H., Ahmad, M., Ahmed, A.T.A., Rahman, A.K.A. and Haque, E.U. (Eds) 2009a.Encyclopedia of Flora and Fauna of Bangladesh, Vol. 7. Angiosperms: Dicotyledons (Balsaminaceae - Euphorbiaceae). Asiatic Society of Bangladesh, Dhaka, pp. 1-546.

Ahmed, Z.U., Hassan, M.A., Begum, Z.N.T., Khondker, M., Kabir, S.M.H., Ahmad, M., Ahmed, A.T.A., Rahman, A.K.A. and Haque, E.U. (Eds) 2009b.Encyclopedia of Flora and Fauna of Bangladesh, Vol. 8. Angiosperms: Dicotyledons (Fabaceae - Lythraceae). Asiatic Society of Bangladesh, Dhaka, pp. 1-478.

Ahmed, Z.U., Hassan, M.A., Begum, Z.N.T., Khondker, M., Kabir, S.M.H., Ahmad, M. and Ahmed, A.T.A. (Eds) 2009c.Encyclopedia of Flora and Fauna of Bangladesh, Vol. 9. Angiosperms: Dicotyledons (Magnoliaceae - Punicaceae). Asiatic Society of Bangladesh, Dhaka, pp. 1-488.

Ahmed, Z.U., Hassan, M.A., Begum, Z.N.T., Khondker, M., Kabir, S.M.H., Ahmad, M. and Ahmed, A.T.A. (Eds) 2009d. Encyclopedia of Flora and Fauna of Bangladesh, Vol. 10. Angiosperms: Dicotyledons (Ranunculaceae - Zygophyllaceae). Asiatic Society of Bangladesh, Dhaka, pp. 1-580.

Alam, S., Uddin, M.Z. and Hassan, M.A. 2006. A Preliminary Checklist of the Angiospermic Flora of Ghagotia Union under Kapasia Upazila in Gazipur district, Bangladesh. Bangladesh J. Plant Taxon. 13(2): 155-170.

Alexiades, M.N. (ed.). 1996. Selected Guidelines for Ethno botanical Research: A Field Manual. The New York Botanical Garden, New York.

Alfasane, M.A., Khondker M., Islam, M.S. and Bhuiyan, M.A.H. 2010. Egeria densa Planchón (Hydrocharitaceae) : A new angiospermic record for Bangladesh. Bangladesh J. Plant Taxon. 17(2): 209-213.

Alfasane, M.A., Ullah, M.S. and Khondker, M. 2013. Limnology of lake Rainkhyongkain of Bangladesh with a new record of Marchantia polymorpha L. var. aquatica Nees. Bangladesh J. Bot. 42(2): 223-229.

Alfasane, M.A., Akhtar, A., Mehnaz. M., Ayesha, A. and Begum, Z.N.T. 2019a. Myriophyllum aqaticum (Vell.) Verdc. (Haloragaceae): A new angiospermic record for Bangladesh. Bangladesh J. Plant Taxon. 26(1): 127-130.

Alfasane, M., Bhuiyan, R., Jolly, J., and Islam, S. 2019b. Azolla microphylla Kaulf. (Salviniaceae): A new pteridophytic record for Bangladesh. Bangladesh J. Plant Taxon. 26(2), 325-327. 
Bolpagni, R. and Piotti, A. 2015. Hydro-hygrophilous vegetation diversity and distribution patterns in riverine wetlands in an agricultural landscape: a case study from the Oglio River (Po plain, Northern Italy). Phytocoenologia 45: 69-84.

Bouma, T. J., De Vries, M.B. and Herman, P. M. J. 2010.Comparing ecosystem engineering efficiency of two plant species with contrasting growth strategies. Ecology 91: 2696-2704.

Chambers, P. A., Lacoul, P., Murphy, K.J. and Thomaz, S.M. 2008. Global diversity of aquatic macrophytes in freshwater. Hydrobiologia 595: 9-26.

Cronquist, A. 1981.An integrated system of classification of flowering plants.Columbia University Press, New York, pp.1262.

Hossain, M.K. and Pasha, M.K. 2004. An account of the exotic flora of Bangladesh. Journal of forestry and environment 2: $99-115.8$

Hunter, M.L. 1995.Fundamentals of Conservation Biology. Blackwell Science, USA. 442pp.

Hyland, B.P.M. 1972. A technique for collecting botanical specimens in rain forest. Flora Malesiana Bulletin, 26: 2038-2040.

Ishaq, M. 1977. Bangladesh district gazetteers, Noakhali Vol.5: Bangladesh Ministry of Cabinate affairs. Establishment Division, Bangladesh Govt. Press.

Khan, M.S. and Halim, H. 1987.Aquatic angiosperms of Bangladesh. BNH, BARC. 120 pp.

Khan, M.S., Rahman MM and Ali MM (eds.) 2001. Red Data Book of Vascular Plants of Bangladesh. Bangladesh National Herbarium. pp. 179.

Mahmuda Z., Haque, T. and Uddin, M.Z. 2017. Taxonomic enumeration of angiosperm flora of Sreenagar Upazila, Munshigang, Dhaka, Bangladesh . J. Asiat. Soc. Bangladesh, Sci. 43(2): 161-172.

Mukhopadhyay G., Sengupta, Sand A. Dewanji,A 2017. Aquatic flora in two Indian ponds near Kolkata, West Bengal: Implications for conservation. Bangladesh J. Plant Taxon. 14(1): 13-24.

O’Hare, M.T., Aguiar, F.C., Asaeda, T., Bakker, E.S., Chambers, P.A., Clayton, J. S., et al. 2017. Plants in aquatic ecosystems: current trends and future directions. Hydrobiologia 153: 1-11

Scheffer, M., Szabó, S., van Nes, E. H., Rinaldi, S., Kautsky, N. and Norberg, J. 2003. Floating plant dominance as a stable state. Proc. Natl. Acad. Sci. U.S.A. 100, 4040-4045.doi: 10.1073/pnas.0737918100

Serker, K, Islam, MR, Uddin, M.Z. and Hassan, M.A. 2013. Angiopermic flora of Manikganj Sadar Upazila. Journal of Asiatic Society. 39(2): 147-166.

Shethi, K.J. and Uddin, M.Z. 2018.Antioxydant properties of five commercially less valued vegetables from Bangladesh. Bangladesh J. Bot. 47(4): 953-959.

Siddiqui, K.U., Islam, M.A., Ahmed, Z.U., Begum, Z.N.T., Hassan, M.A., Khondker, M., Rahman, M.M., Kabir, S.M.H., Ahmad, M., Ahmed, A.T.A., Rahman, A.K.A. and Haque, E.U. (Eds) 2007. Encyclopedia of Flora and Fauna of Bangladesh, Vol. 11. Angiosperms: Monocotyledons (Agavaceae Najadaceae). Asiatic Society of Bangladesh, Dhaka, pp. 1-399.

Soana, E. and Bartoli, M. 2014. Seasonal regulation of nitrification in a rooted macrophyte (Vallisneria spiralis L.) meadow under eutrophic conditions. Aquat. Ecol. 48: 11-21.

Uddin M.Z., Kibria, M.G. and Hassan, M.A. 2014.Study of ethnomedicinal plants used by the local people of Feni district. Journal of Asiatic Society 41(2): 203-223.

Uddin, M.Z. and Hassan, M.A. 2004. Flora of Rema-Kalenga Wildlife Sanctuary. IUCN Bangladesh Country Office, Dhaka, Bangladesh, vi+120pp. 